\title{
Rezime
}

Valutne opcije se često koriste za ublažavanje valutnih rizika proisteklih iz korporativnih aktivnosti. Njihova primena može biti kompleksna a problemi nastaju ako se suštinski elementi i principi u potpunosti ne razumeju. Iako nisu najjednostavniji finansijski proizvod, valutne opcije su zanimljive i korisne onima koji pokušavaju da naprave korak dalje na području upravljanja valutnim rizikom.

Ovaj rad ima za cilj da prikaže opšta načela i specifičnosti računovodstvenog evidentiranja i vrednovanja valutnih opcija koje se koriste za zaštitu od rizika. Rečje o složenom procesu koji obuhvata, osim brojnih uslova, i primenu računovodstvenih pravila koja odstupaju od opšteprihvaćenih računovodstvenih principa.

Ključne reči: devizni kurs, fer vrednost, hedžing, MRS 39, računovodstvo zaštite, valutne opcije, valutni rizik 


\section{ACCOUNTING TREATMENT OF CURRENCY OPTIONS}

Danica Prošić

Master World d.o.o. danicaprosic@eunet.rs

Translation provided by the author

\section{Summary}

Currency options are often used to mitigate currency risk resulting from corporate activities. Their implementation can be complex, and there could be problems if the essential elements and principles are not fully understood. Although they are not the simplest financial products, currency options are interesting and useful to those who are trying to make a step forward in the area of currency risk management.

This paper aims to present the general principles and specifics of accounting records and valuation of currency options used for hedging against risk. It is a complex process which, in addition to numerous conditions, also involves the implementation of accounting rules that deviate from the generally accepted accounting principles.

Keywords: exchange rate, fair value, hedging, IAS 39, hedge accounting, currency options, currency risk

JEL: G23, M16 


\section{Uvod}

U dinamičnom svetu finansija, upotreba finansijskih derivata širokog spektra rasla je velikom brzinom u poslednje dve decenije. Njihova globalna popularnost dolazi, pre svega, kao posledica izrazito raznorodnih aspekata njihove primene $u$ zaštiti od rizika. Ovaj trend primorao je Međunarodne računovodstvene organizacije da regulišu ovu oblast, odnosno, da dođu do odgovarajućih računovodstvenih standarda za npr. hedžing aktivnosti kako bi se povećao kvalitet $\mathrm{i}$ homogenost informacija u vezi korišćenja derivata u upravljanju korporativnim rizicima. To je oblast koja u skladu sa postojećim računovodstvenim zahtevima MRS 39 ima ozbiljan uticaj na poslovne odluke. Stoga su uspostavljeni posebni računovodstveni standardi za hedžing aktivnosti i obelodanjivanja o derivativnim instrumentima $u$ finansijskim izveštajima. Na tom području primenjuju se odredbe MRS i MSFI koje regulišu priznavanje, merenje i objavljivanje informacija o finansijskim derivatima. Više informacija o izloženosti riziku i politikama zaštite od rizika omogućava tržištu da bolje proceni odluke subjekta. MRS 39 propisuje principe za priznavanje i merenje finansijskih instrumenata, uključujući i derivate. Prema MSFI svi derivati, bez obzira da li se koriste za hedžing ili svrhe trgovanja mere se i prikazuju po fer vrednosti a sve promene $u$ fer vrednosti iskazuju u bilansu uspeha ili kroz kapital.

Prema definiciji, valutni rizik se javlja kao posledica promena deviznog kursa između dve valute. Slično, jednu od brojnih definicija valutnog rizika dali su Eiteman, at. all. (2001, str. 37): "Valutni rizik je verovatnoća da će neočekivana promena deviznog kursa promeniti iznos domaće valute potreban za plaćanje duga u stranoj valuti". Raspoloživi instrumenti zaštite su ogromni, kako po raznovrsnosti tako i kompleksnosti a koji prate dramatičan porast potreba za specifičnim hedžingom savremene firme (Hakala and Wystup, 2002; Jacque, 1996; Shapiro, 1996). Opcije zauzimaju značajno mesto u finansijskom poslovanju na međunarodnoj sceni. Idealne su za zauzimanje pozicija, zaštitu već postojećih rizika, kreiranje potrebnog novčanog toka a sve to uz ogroman nivo fleksibilnosti.

Zbog varijeteta sa kojim se nude, može se stvoriti skoro beskonačno mnogo strategija koje mogu biti prilagođene sopstvenim potrebama i sa različitim nivoima rizičnosti. Dodatno, jedna od kombinacija opcija razvijena je za postizanje posebnih zahteva u upravljanju valutnim rizikom. Sklonost ka valutnim opcijama naročito je izražena kod onih koji očekuju primitke novca iz inostranstva i kod onih koji žele da se zaštite od nepovoljne promene deviznog kursa. Valutne opcije sa aspekta vremena nastanka čine najmlađu grupu finansijskih derivata. Njima se trguje na brojnim organizovanim berzama širom sveta, uključujući Philadelphia Stock Ekchange (PHLX) i London International Financial Futures Exchange (LIFFE). Prvi opcijski ugovori koji glase na stranu valutu zabeleženi su 1982, godine na Filadelfijskoj berzi (PHLKS). Od tada, uporedo sa povećanjem trgovine derivata, trgovanje opcijama ušlo je u fazu eksplozivnog rasta.
Tabela 1. Trgovina valutnim opcijama na organizovanim berzama (broj ugovora u milionima) podaci za Q1 2015 objavljeni 8. juna 2015.

\begin{tabular}{|l|c|c|c|c|c|c|}
\hline Promet \\
\hline Lokacija & 2013 & 2014 & Q2 2014 & Q3 2014 & Q4 2014 & Q1 2105 \\
\hline Sva tržišta & 403.9 & 248.7 & 34.8 & 57.8 & 105.9 & 132.4 \\
\hline $\begin{array}{l}\text { Severna } \\
\text { Amerika }\end{array}$ & 15.4 & 17.3 & 3.2 & 5.0 & 5.4 & 5.9 \\
\hline Evropa & 4.2 & 43.6 & 1.0 & 2.2 & 38.4 & 3.9 \\
\hline Azija i Pacifik & 354.0 & 154.1 & 23.0 & 43.0 & 51.5 & 113.6 \\
\hline Ostala tržišta & 30.4 & 33.7 & 7.6 & 7.5 & 10.6 & 9.0 \\
\hline
\end{tabular}

Osim na organizovanim tržištima (standardizovano) valutnim opcijama se trguje i na OTC tržištu (fleksibilno). Ključna prednost OTC opcija je da su prilagođene specifičnim potrebama firme. Veoma brz razvoj različitih struktura valutnih opcija pripisuje se upravo njihovoj fleksibilnoj prirodi. U Srbiji ne postoji formalno organizovano tržište derivata, njima se trguje na OTC tržištu gde banke nude svojim klijentima, za sada samo tri vrste derivata: valutni forward, valutne i kamatne svopove. Međutim, sve banke ne nude sva tri oblika derivata, već je ponuda kreirana u odnosu na obim i veličinu same banke. Ovaj rad omogućuje 


\section{Introduction}

In the dynamic world of finance, the use of a wide range of financial derivatives has increased rapidly in the last two decades. Their global popularity is primarily a result of the extremely diverse aspects of their use in hedging. This trend has forced the international accounting organizations to regulate the area, i.e. to adopt the appropriate accounting standards, for example for hedging activities, in order to increase the quality and homogeneity of information regarding the use of derivatives in managing corporate risks. This is an area which, in accordance with the existing accounting standards - IAS 39, has a serious impact on business decisions. Therefore, separate accounting standards for hedging activities and disclosures on derivative instruments in financial statements have been established. In this area, the provisions of IAS and IFRS apply, which regulate the recognition, measurement and disclosure of information on financial derivatives. More information on risk exposure and hedging policies allows the market to better assess the entities' decisions. The IAS 39 prescribes principles for recognizing and measuring financial instruments, including derivatives. Under IFRS, regardless of whether they are used for hedging or trading purposes, all derivatives are measured and recorded at fair value, while all changes in fair value are declared in the income statement or in equity.

By definition, currency risk arises as a result of changes in the exchange rate between the two currencies. Similarly, one of many definitions of currency risk was given by Eiteman, et al. (2001, p.

37): 'Currency risk is the probability that an unexpected change in the exchange rate will change the amount of local currency needed to pay the debt in foreign currency'. The available hedging instruments are various, both in terms of their diversity and complexity, and they follow a dramatic increase of the need for specific hedging of a modern company (Hakala and Wystup, 2002; Jacque, 1996; Shapiro, 1996). Options have an important role in financial operations at the international level. They are ideal for positioning, hedging against the already existing risks, accumulation of the necessary cash flow, and all that with a high degree of flexibility.

Because of the variety of forms in which they are offered, one can create almost an infinite number of strategies that can be tailored to individual needs and with different levels of risk. In addition, one of the combinations of options has been developed for achieving specific requirement in managing currency risk. The tendency towards currency options is particularly evident among those who expect inflows of funds from abroad, as well as those who want to protect themselves from adverse changes in exchange rates. Considering the time of their appearance, currency options are ranked as the youngest group of financial derivatives. They are traded on various organized stock exchanges around the world, including the Philadelphia Stock Exchange (PHLX) and the London International Financial Futures Exchange (LIFFE). The first option contracts denominated in foreign currency were recorded in 1982 on the Philadelphia Stock Exchange (PHLKS). Since then, options trade has entered a stage of dramatic growth, along with the increased trade in derivatives.

Table 1. Currency options trade in organized stock exchanges (number of contracts in millions) data for Q1 2015 released on June 8, 2015

\begin{tabular}{|l|c|c|c|c|c|c|}
\hline Turnover \\
\hline Location & 2013 & 2014 & Q2 2014 & Q3 2014 & Q4 2014 & Q1 2105 \\
\hline All markets & 403.9 & 248.7 & 34.8 & 57.8 & 105.9 & 132.4 \\
\hline North America & 15.4 & 17.3 & 3.2 & 5.0 & 5.4 & 5.9 \\
\hline Europe & 4.2 & 43.6 & 1.0 & 2.2 & 38.4 & 3.9 \\
\hline Asia and Pacific & 354.0 & 154.1 & 23.0 & 43.0 & 51.5 & 113.6 \\
\hline Other markets & 30.4 & 33.7 & 7.6 & 7.5 & 10.6 & 9.0 \\
\hline
\end{tabular}

Source: http://www.bis.org

Except in organized markets (standardized), currency options are also traded on the OTC market (flexible). The key advantage of OTC options is that they are adapted to the specific needs of a company. A very fast development of various structures of currency options can particularly be attributed to their flexible nature. There is no formally organized market of derivatives in Serbia; they are traded on the OTC market, where banks have so far 
bolje razumevanje računovodstvenog praćenja valutnih opcija kada su deo hedžing transakcija kako bi se u većoj meri mogle uvrstiti u program upravljanja valutnim rizikom.

\section{Elementi i tipovi ugovora o valutnoj opciji}

Valutna opcija je ugovor između kupca i prodavca. Kupac opcije stiče na ograničeno vreme pravo da kupi ili proda neku valutu po određenoj ceni. Za to pravo on plaća premiju ili cenu. Prodavac opcije prima uplatu od kupca i preuzima obavezu da ispuni uslove iz ugovora ukoliko kupac ostvaruje pravo iz opcije. Bez obzira na vrstu opcije, potencijalni gubitak svodi se na premiju, (ograničen rizik). Ova opcija štiti kupca od negativnih kretanja deviznog kursa i istovremeno daje teoretski neograničene mogućnosti profita u zavisnosti od smera kretanja datog deviznog kursa. Prema pravu koje daju postoje dva tipa opcija: opcija kupovine (call) i opcija prodaje (put). Kupovinom put opcije, imalac će biti zaštićen od pada sadašnjeg deviznog kursa (spot), dok ima koristi od njegovog povećanja. Kako se tržišta derivata mogu posmatrati kao svojevrsne kladionice, tako i za kupovnu put opciju može se kazati da predstavlja postavljanje opklade da će spot kurs biti ispod izvršnog kursa. Kupovinom kupovne (call) opcije, investitor se štiti od rasta deviznog kursa i istovremeno ostvaruje korist od njegovog pada. To se takođe, može posmatrati kao postavljanje opklade da će spot kurs biti iznad izvršnog kursa.

Valutne kupovne i prodajne opcije raspoložive su u evropskoj i američkoj varijanti. Mogu se izvršiti na dan dospeća u slučaju opcije evropskog tipa ili na bilo koji datum do dospeća uključujući i taj datum u slučaju američkog tipa opcije. Američki tip je mnogo složeniji, što posebno dolazi do izražaja u procesu vrednovanja opcije. Kako američka opcija može biti izvršena u bilo kom trenutku u vremenu svog trajanja, krajnji profit na opciju će u velikoj meri zavisiti od politike izvršenja koju vlasnik sprovodi. Na datum dospeća, ukoliko se pre toga američka opcija nije izvršila, sprovešće se ista strategija za izvršenje opcije kao u slučaju evropskih opcija.

\section{Izvršenje opcijskog ugovora}

Iskorišćenje prava datog opcijom naziva se izvršenje. Opcije su po pravilu kratkoročni finansijski instrumenti čije vreme dospeća ne prelazi devet meseci. Banke najčešće dozvoljavaju opcije sa istekom u periodu ne dužem od tri meseca. S tim u vezi, kupac valutne opcije ima na raspolaganju tri mogućnosti: (1) da iskoristi opciju, (2) da je proda na sekundarnom tržištu i (3) da je ne iskoristi (da pusti da istekne). Tako je na dan dospeća:

- opcija u novcu ("in-the - money") kada se može izvršiti,

- na istom "at-the-money" kada je nivo osnovnog deviznog kursa jednak izvršnoj ceni i

- opcija izvan novca "out-of-the-money" kada se ne može izvršiti.

Preciznije, ako je trenutni devizni kurs niži od izvršnog, imalac call opcije će se radije odlučiti za kupovinu strane valute po sadašnjem kursu nego da opciju izvrši. Ukoliko je spot kurs viši ili jednak izvršnom kursu, imalac call opcije će je izvršiti i tako kupiti stranu valutu po izvršnoj ceni. Kada je spot kurs viši od izvršnog kursa "out-of-the-money", imalac put opcije će se radije odlučiti da proda devize po spot kursu, nego da put opciju izvrši. Ako je spot kurs niži ili jednak izvršnom kursu "inthe-money", imalac će put opciju izvršiti i na taj način prodati stranu valutu po izvršnom deviznom kursu.

\section{Vrednovanje valutne opcije sa računovodstvenog aspekta}

Pitanje vrednovanja opcije je jedno od najzanimljivijih područja finansijske teorije. Svaka valutna opcija ima svoju vrednost u svakom trenutku do datuma dospeća. Međutim, postoji niz faktora koji utiču na tu vrednost koji otežavaju stvaranje predstave o tome da li je cena opcije razumna ili ne. To znači da se vrednost opcije menja prilikom promene sledećih faktora: spot devizni kurs, izvršni devizni kurs, datum dospeća opcije, nerizična kamatna stopa za valute koje čine devizni kurs i varijabilnost deviznog kursa. Valutne opcije su posebno dragocene tokom perioda visokih varijabilnosti deviznih kurseva ali iz perspektive 
offered their customers only three types of derivatives: currency forward, currency swaps and interest rate swaps. However, all banks do not offer all three types of derivatives: the offer is created in relation to the scope and size of the banks themselves. This paper provides a better understanding of the accounting records of currency options when they are a part of hedging transactions so that they could be included into currency risk management program to a greater extent.

\section{The elements and types of currency options contracts}

A currency option is a contract between a buyer and a seller. The buyer of the option acquires the right, for a limited period of time, to buy or sell a currency at a specific price. For this right he pays a premium or a price. The seller of the option receives a payment from the buyer and undertakes to fulfill the contract terms if the buyer exercises the right from the option. Regardless of the type of option, the potential loss is reduced to the premium (a limited risk). This option protects the buyer from adverse exchange rate movements and at the same time gives theoretically unlimited possibilities for profits, depending on the direction of the given exchange rate movement. In terms of the right they grant, there are two types of options: a purchasing (call) option, and a selling (put) option. By purchasing a put option, the holder will be protected from the fall of the current exchange rate (spot), but also benefit from its increase. Since the derivatives markets can be considered to be a kind of a betting shop, it can also be said that purchasing a put option represents a bet that the spot exchange rate will be below the execution rate. By purchasing a call option, the investor is protected against the growth of the exchange rate and at the same time benefits from its fall. It can also be seen as putting a bet that spot exchange rate will be higher than the execution exchange rate.

Foreign exchange buying and selling options are available in the European and American versions. They can be made on the maturity date in the case of European-type options, or on any date up to and including the maturity date in the case of American-type options. The
American type is much more complex, which is especially evident in the process of evaluating options. As an American option can be exercised at any point of its duration, the final profit from the option will largely depend on the exercise policy implemented by the owner. On the maturity date, unless the American option has not been exercised previously, the same strategy will be implemented for its exercise as in the case of European options.

\section{The enforcement of the option contract}

The exercise of the rights given by the option is called execution. As a rule, options are shortterm financial instruments whose time of maturity does not exceed nine months. Banks usually allow for options expiring in the period not longer than three months. In this regard, the currency options buyers have three possibilities on their disposal: (1) to make use of the option, (2) to sell it on the secondary market, and (3) not to make use of it (to let it expire). Thus, on the maturity date:

- the option is 'in-the -money' when it can be exercised,

- the option is 'at-the-money' when the level of the basic exchange rate is equal to the exercise price and

- the option is 'out-of-the-money' when it cannot be exercised.

More specifically, if the current exchange rate is lower than the exercise rate, the holder of the call option will rather opt for the purchase of foreign currency at the current exchange rate than exercise the option. If the spot exchange rate is higher than or equal to the exercise rate, the holder of the call option will exercise it, thus buying foreign currency at the exercise price. When the spot exchange rate is higher than the exercise 'out-of-the-money' rate, the holder of the put option will rather choose to sell foreign currency at spot exchange rate, than to exercise the put option. If the spot exchange rate is lower than or equal to the exercise 'inthe-money' rate, the holder will exercise the put option, thus selling foreign currency at the exercise exchange rate. 
kupca visoka varijabilnost rezultuje sa višim cenama opcije. Promene cena i volumena put i call opcija mogu biti indukovane ili povećanom hedžing aktivnosti ili povećanjem špekulacija (Lung, Pei Peter, 2001, str. 49).

U praksi se cena opcije utvrđuje primenom različitih tehnika procene. Najčešće se koriste Binomni model cena valutnih opcija i BlackScholes-ov model cena evropskih valutnih opcija. Međutim, najbolji dokaz vrednosti opcije je kotirana cena na aktivnom tržištu. Ako tržište za finansijski instrument nije aktivno, subjekt utvrđuje vrednost primenom tehnika procene.

Opcija ima tzv. intrinsičnu i vremensku vrednost. Intrinsična vrednost valutne opcije predstavlja razliku između izvršne cene (strike) i sadašnje (spot) cene valute. Vremenska vrednost opcije je verovatnoća da će u preostalom vremenu do dospeća opcija napredovati u opciju u novcu "in the money" kada će se moći izvršiti. Što je duži period do dospeća opcije, vremenska vrednost opcije će biti veća. MRS 39 (tačka 74.a) dopušta subjektu da intrinsičnu vrednost ugovora o opciji odvoji od njegove vremenske vrednosti i kao hedžing instrument odredi samo promenu intrinsične vrednosti ugovora o opciji. To može dovesti do hedžing odnosa koji je savršeno efikasan $\mathrm{u}$ kompenzaciji promena novčanih tokova povezanih sa zaštićenom prognoziranom transakcijom sa jednostranim rizikom ako su glavni uslovi predviđene transakcije i hedžing instrumenta isti. Ako subjekt celu kupljenu opciju odredi kao instrument zaštite od jednostranog rizika povezanog sa predviđenom transakcijom, hedžing odnos neće biti savršeno efikasan zato što premija plaćena za opciju uključuje vremensku vrednost, dok jednostrani rizik određen za zaštitu prema tačci UP.99.BA, ne uključuje vremensku vrednost opcije. Konkretno, u takvoj situaciji neće biti kompenzacije između novčanih tokova povezanih sa vremenskom vrednošću plaćene premije za opciju i određenog zaštićenog rizika.

\section{Mehanizam računovodstva zaštite}

Računovodstvo zaštite je tehnika koja usklađuje promene fer vrednosti instrumenta za zaštitu i štićene stavke u Bilansu uspeha i Izveštaju o ostalom rezultatu. Kako bi činjenice o ovome bile jasnije mi ćemo se u nastavku ovog teksta potruditi da tehniku računovodstva zaštite približimo što detaljnije. Instrumenti kapitala i stavke hedžinga pripadaju grupi kompleksnih finansijskih instrumenata na koje se primenjuje MRS 39 i Odeljak 12 MSFI za MSP. Prema definiciji MRS 39, derivati se uvek svrstavaju u kategoriju finansijskog sredstva ili finansijske obaveze koji se drže radi trgovanja. Jedini izuzetak su finansijski instrumenti namenjeni za zaštitu od rizika - hedžing. Kako se derivati često koriste za ublažavanje rizika (kao što su kamatni ili valutni rizik) koji proizilaze iz korporativnih aktivnosti, standardni računovodstveni tretman instrumenata za zaštitu podrazumeva da se promene fer vrednosti moraju evidentirati kroz bilans uspeha. Instrumenti za zaštitu i štićena sredstva/obaveze se često mere po (amortizovanoj) nabavnoj vrednosti ili fer vrednosti i iskazuju kroz kapital. Međutim, prognozirane stavkečesto sene priznaju u bilansu stanja. To dovodi do (privremenog) vrednovanja ili vremenskog neslaganja između štićene stavke i instrumenta za zaštitu. Cilj računovodstva zaštite je da se izbegnu privremene neželjene kolebljivosti u dobitku/gubitku kao rezultat ovih vrednovanja i vremenske razlike.

Ostali ukupan rezultat (OCI - Other Comprehensive Result) predstavlja novinu u finansijskom izveštavanju. Već godinama su neke od njegovih komponenti iskazivane preko kapitala bez uključivanja u izveštaj o rezultatu. Dobitak ili gubitak na osnovu zaštite priznati u ukupnom ostalom rezultatu treba da se reklasifikuju u dobitak ili gubitak kada se štićena stavka prizna u dobitak ili gubitak ili kada se hedžing odnos završi. Međutim, subjekti mogu da primenjuju računovodstvo zaštite samo ako ispunjavaju brojne i složene uslove iz MRS 39.

Prema MRS 39, zaštita mora da se odnosi na konkretan identifikovani i određeni rizik da bi se kvalifikovala za računovodstvo zaštite i u krajnjoj instanci mora uticati na neto dobitak ili gubitak. Računovodstvo zaštite primenjuje se uz uslov da su zaštitni odnosi dozvoljeni po MRS 39 i da su sva utvrđivanja, dokumentacija i zahtevi efikasnosti ispunjeni (Accounting Standards Council, 2006). Subjekt treba da prizna:

- u ukupnom ostalom rezultatu deo promene fer vrednosti instrumenta za zaštitu koja je 


\section{Currency option valuation from the accounting point of view}

The issue of option evaluation is one of the most interesting areas of financial theory. Each currency option has its own value at any time prior to maturity date. However, there are a number of factors that affect that value, and that hinder getting the idea as to whether the option price is reasonable or not. This means that the value of an option changes with the change of the following factors: the spot exchange rate, the exercise exchange rate, the maturity date of the option, the risk-free interest rate for currencies that make up the exchange rate and the exchange rate variability. Currency options are especially valuable during the periods of high variability of foreign exchange rates, but from the customer's perspective high variability results in higher option prices. Changes in prices and volume of put and call options can be induced by either the increased hedging activity or the increase of speculation (Lung, Pei Peter, 2001, p. 49).

In practice, the price of an option is determined by using different evaluation techniques. The most commonly used are the Binomial model of currency options prices and the Black-Scholes model of the European currency options prices. However, the best evidence of the option value is the quoted price in an active market. If the market for a financial instrument is not active, an entity determines the value by using evaluation techniques.

The option has the so-called intrinsic and time value. The intrinsic value of a currency option is the difference between the exercise price (strike) and the current (spot) price of currency. The time value of an option is probability that in the remaining time to maturity the option will advance into the 'in the money' cash option, when it will be possible to exercise it. The longer the period to maturity of the option, the higher its time value. IAS 39 (item 74a) allows an entity to separate the intrinsic value of an option contract from its time value, and, as a hedging instrument, determine only the intrinsic value of an option contract. This may result in a hedging relationship that is perfectly effective in compensating the changes of the cash flows associated with the hedged projected transaction with a one-sided risk, if the key conditions of the projected transaction and of hedging instrument are the same. If an entity determines the whole of the purchased option to be a hedging instrument against one-sided risk associated with the projected transaction, the hedging relationship will not be perfectly efficient because the premium paid for the option includes time value, while onesided risk designated for hedging under UP.99. BA does not include time value of the option. In particular, in such a situation there is no compensation between the cash flows related with the time value of the premium paid for the option and a particular hedged risk.

\section{Hedge accounting mechanism}

Hedge accounting is a technique that aligns the changes in hedging instrument fair value and the hedged item in the Income Statement and Statement of Other Comprehensive Income. To make the facts about this clearer, further on we shall try to present the hedge accounting technique into more detail. Capital instruments and hedging items belong to the group of complex financial instruments to which IAS 39 and Section 12 of IFRS for SMEs apply. As defined by IAS 39, derivatives are always classified in the category of financial assets or financial liabilities held for trading. The only exception refers to the financial instruments used for the protection against risk or hedging. As derivatives are often used to mitigate risks (such as interest rate or currency risk) arising from corporate activities, the standard accounting treatment of hedging instruments means that the changes in fair value must be recorded in the Income Statement. Hedging instruments and hedged assets / liabilities are often measured at (depreciated) cost value or fair value and are declared in equity. However, the projected items are often not recognized in the balance sheet. This leads to a (temporary) evaluation or timing discrepancies between the hedged items and the hedging instrument. The aim of hedge accounting is to avoid unwanted temporary volatility in profit / loss as a result of such valuation and time difference.

Other Comprehensive Result (OCI) is an innovation in financial reporting. For years, 
bila efektivna $u$ eliminisanju promena fer vrednosti ili očekivanih tokova gotovine štićene stavke;

- u dobitak ili gubitak svaki višak fer vrednosti instrumenta za zaštitu preko promene fer vrednosti očekivanih tokova gotovine što se ponekad naziva neefektivnost zaštite.

Postoje tri vrste hedžing odnosa (MRS 39, paragraf 86):

- zaštita fer vrednosti;

- zaštita tokova gotovine $\mathrm{i}$

- zaštita neto investicije u inostrano poslovanje kao što previđa MRS 21.

Konkretno, MRS 39 obuhvata širi spektar rizika koji mogu da budu zaštićeni u odnosu na odeljak 12 MSFI za MSP kao što su jednostrani rizici, finansijski instrumenti sa fiksnom stopom koji su zaštićeni za promene fer vrednosti bezrizične ili referentne kamatne stope i dr. Štaviše, MSFI i MSP dozvoljavaju računovodstvo zaštite samo za sledeće rizike:

- rizik kamatne stope dužničkih instrumenata koji se odmerava po amortizovanoj vrednosti;

- rizik deviznog kursa ili kamatne stope u čvrstoj obavezi ili veoma verovatnoj predviđenoj transakciji,

- rizik cene robe koja se drži ili predstavlja čvrstu obavezu ili veoma verovatnu predviđenu transakciju kupovine ili prodaje robe,

- rizik deviznog kursa u neto investiciju u inostrano poslovanje.

Sa računovodstvenog aspekta zaštita od valutnog rizika utvrđene obaveze može se posmatrati kroz dve prizme: (1) kroz prizmu zaštite fer vrednosti ili (2) kroz prizmu zaštite tokova gotovine.

Nakon što su izložene osnovne karakteristike koncepta sada nam ostaje da na pojednostavljenom primeru ilustrujemo tehmiku zaštite tokova gotovine kao jednog od modela računovodstva zaštite. Da bi na najbolji način prezentovali navedenu tehniku izabran je period 2003/2004 godine kada su se dogodile velike turbulencije na svetskom finansijskom tržištu koje su značajno uticale na promene vrednosti većine svetskih valuta. Tada je došlo i do izuzetne varijabilnosti kursa USD/EUR.
Na dan 26.11.2003. godine evropski izvoznik je planirao izvoz robe u USA sa sledećim karakteristikama:

- vrednost izvoza 950.000,00 USD;

- rok isporuke robe 17.02.2004. i

- rok naplate potraživanja 14.03.2004.

Na osnovu dostupnih informacija predviđa se nestabilnost USD tako da bi njegovo pomeranje u nepovoljnom smeru moglo dovesti u pitanje profitabilnost predviđene transakcije. Stoga je donesena odluka o zaštiti izloženosti valutnom riziku. Kupljena je prodajna opcija evropskog tipa sa pravom prodaje 950.000,00 USD na dan 14.03.2004. godine po unapred ugovorenom kursu. Za to je banci plaćena premija u iznosu od 16.691,50 EUR. Međutim, ovde treba imati u vidu činjenicu da će potraživanje po osnovu izvozne transakcije biti naplaćano tek mesec dana nakon isporuke robe i da cena valutne opcije zavisi od vremena koje je preostalo do datuma njenog dospeća. Preciznije, što je preostalo vreme duže, veća je verovatnoća da će se cene na tržištu promeniti i da će se opcija izvršiti kao "in the money".

\section{Ocena varijabilnosti deviznog kursa USD/EUR i izračunavanje rizične vrednosti predviđene transakcije}

Rizična vrednost predstavlja očekivani gubitak koji subjekt može da pretrpi zbog uticaja varijabilnosti faktora rizika na predviđenu transakciju. Uobičajeno, problematika utvrđivanja rizične vrednosti kreće od određivanja štićene stavke i faktora rizika kojem je predviđena transakcija izložena. To je devizni kurs USD/EUR. Ovde je domaća valuta EUR a strana USD. Da bi se odredio devizni kurs u budućnosti mora da se pođe od svih dostupnih informacija u vezi sa njegovim kretanjem na tržištu do tog trenutka. Stoga su radi procene varijabilnosti deviznog kursa USD/ EUR posmatrane njegove dnevne vrednosti u prethodnoj godini sa kursne liste (www.ecb/ historical-exchange-rates). 
some of its components have been presented through equity, without their inclusion in the report on the result. Profit or loss based on hedging recognized in other comprehensive result must be reclassified into profit or loss after the hedged item is recognized as profit or loss or when the hedging relationship ends. However, entities may apply hedge accounting only if they meet the numerous and complex requirements of IAS 39.

Under IAS 39, hedging must refer to a specific identified risk to qualify for hedge accounting, and ultimately has to affect net profit or loss. Hedge accounting is applied under the condition that the hedging relations are allowed under IAS 39 and that all identification, documentation and effectiveness requirements are met (Accounting Standards Council, 2006). An entity should recognize:

- in other comprehensive result, a part of the change in fair value of the hedging instrument which has been effective in eliminating the changes in fair value or the expected cash flows of the protected items;

- any surplus of fair value of the hedging instrument as profit or loss, through fair value change of the expected cash flows, which is sometimes referred to as hedging ineffectiveness.

There are three types of hedging relationships (IAS 39, paragraph 86):

- fair value hedging;

- cash flow hedging and

- hedging of net investments in foreign operations as stipulated by the IAS 21 .

In particular, IAS 39 covers a wider range of risks that may be hedged against in terms of section 12 of IFRS for SMEs, such as one-sided risks, financial instruments with fixed rates that are hedged against the fair value change, riskfree or reference interest rate, etc. Moreover, IFRS for SMEs allow hedge accounting only for the following risks:

- risk against interest rate on debt instruments which is measured at depreciated cost;

- exchange rate or interest rate risk in a solid obligation or highly probable predicted transaction,

- risk of prices of goods which are held or represent a firm obligation or highly predicted transaction of purchase or sale of goods,

- exchange rate risk from a net investment in a foreign operation.

From the accounting point of view, hedging against currency risk of the defined obligation can be observed through two prisms: (1) through the prism of fair value protection, or (2) the prism of cash flows protection.

Once we have introduced the basic features of the concept, we can now illustrate, on a simplified example, the cash flows hedging technique, as one of the models of hedge accounting. In order to present the previously mentioned technique in the best way possible the period of 2003/2004 was chosen, the time when the major turbulence occurred on the global financial market which brought about significant changes in the value of most world currencies. At that time an exceptional variability of USD / EUR exchange rate was also recorded.

On November 26, 2003, a European exporter planned to export goods to the USA with the following characteristics:

- export value of \$950,000.00;

- delivery of goods by February 2, 2004 and

- enforcement of claims on March 14, 2004.

Based on the information available the instability of USD was predicted, and its movement in an unfavorable direction could jeopardize the profitability of the planned transaction. Therefore, a decision was made to hedge against the currency risk. A Europeantype put option was purchased with the sale right of 950,000.00 USD on March 14, 2004 at the pre-agreed exchange rate. For that a premium was paid at the Bank in the amount of $€ 16,691.50$. However, it should be borne in mind that the claim on the basis of the export transaction will be enforced only one month after the delivery of the goods and that the price of currency option depends on the time remaining until its maturity date. More specifically, the longer the remaining time, the greater the probability that the prices in the market will change and that the option will be executed as 'in the money'. 
Grafik 1. Dnevno kretanje deviznog kursa USD/EUR od 25.11.2002. do 25.11.2003.

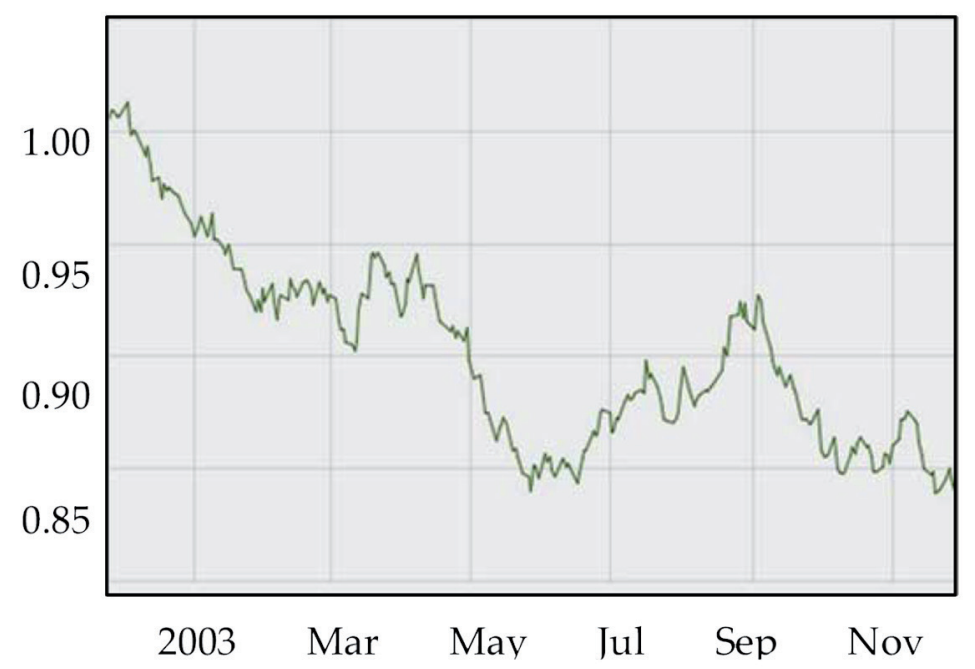

Izvor: European Central Bank

Nakon toga merimo izloženost veoma verovatne predviđene transakcije prodaje robe valutnom riziku. Zatim vršimo ocenu varijabilnosti deviznog kursa i izračunavamo rizičnu vrednost $(\mathrm{VaR})$ predviđene transakcije prodaje robe. Nakonizračunavanja varijabilnosti faktora rizika neophodno je odrediti vremenski period za koji se izračunava VaR. To je u ovom slučaju 76 dana. Godišnja varijabilnost ( $\sigma$ ) USD/ EUR se izračunava na osnovu njegovih dnevnih varijabilnosti u prethodnoj godini po formuli: $\sigma$ godišnja $=\sigma_{\text {periodična }} \times \sqrt{B P}$ - pri čemu je: $\mathrm{BP}$ - broj perioda uzetih u obzir. $\sigma=0,0064 \times 8,717797887$ $=0,055793906$.

I na kraju odredićemo stopu signifikance. VaR izračunavamo sa $95 \%$ signifikancom $(1,65$ standardnih devijacija). Prema opštem obrascu, rizična vrednost se izračunava kao proizvod vrednosti izložene stavke (VIS), varijabilnosti faktora rizika kome je stavka izložena $(\sigma)$ i standardne devijacije (S) u skladu sa izabranom signifikancom. VaR $=$ VIS * $\sigma$ * S (Holton, Glyn, 2003). VaR=803.178,90 x 0,055793906 x $1,65=73.940,61$ EUR.
Tabela 2. Izračunavanje rizične vrednosti (VaR)

\begin{tabular}{|l|r|}
\hline Nominalna vrednost & $950.000,00$ USD \\
\hline $\begin{array}{l}\text { Spot kurs } \\
1 \text { EUR }=1,1828 \text { USD }\end{array}$ & $803.178,90$ EUR \\
\hline $\begin{array}{l}\text { Dnevna varijabilnost kursa } \\
\text { USD/EUR }\end{array}$ & $0,64 \%$ \\
\hline Period izračunavanja VaR-a & 110 dana \\
\hline Broj radnih dana & 76 \\
\hline Signifikanca & $95 \%$ \\
\hline Rizična vrednost (VaR) & $73.940,61 \mathrm{EUR}$ \\
\hline $\begin{array}{l}\text { Udeo VaR-a u štićenoj } \\
\text { stavci }\end{array}$ & $9,21 \%$ \\
\hline
\end{tabular}

Imajući u vidu visoku varijabilnost deviznog kursa USD/EUR i rizičnu vrednost donesena je odluka o zaštiti predviđene transakcije prodaje robe od valutnog rizika. Zaključen je ugovor o evropskoj prodajnoj opciji koja će omogućiti na dan 14.03.2004. pravo prodaje 950.000,00 USD nakon naplate potraživanja po važećem kursu na dan zaključenja ugovora 26.11.2003. godine. Konkretno, zaključena je "at-the-money" opcija koja u slučaju trenutnog izvršenja dovodi do 


\section{The USD/EUR exchange rate variability assessment and VaR calculation of the predicted transaction}

Value at risk represents the expected loss that an entity may undergo due to the impact of risk factors variability on the predicted transaction. Typically, the issue of determining risk levels starts from determining the hedged item and risk factors to which the planned transaction is exposed. This is the exchange rate of USD / EUR. Here a domestic currency is EUR, while the foreign one is USD. In order to determine the exchange rate in the future one must start from all available information related to its movements in the market up to that point. Therefore, to assess the variability of the USD / EUR exchange rate, the daily values of the exchange rate from the previous year were observed (www.ecb/historical-exchange-rates).

Graph 1. Daily fluctuations of the USD/EUR exchange rate from Nov. 252002 until Nov. 25.2003

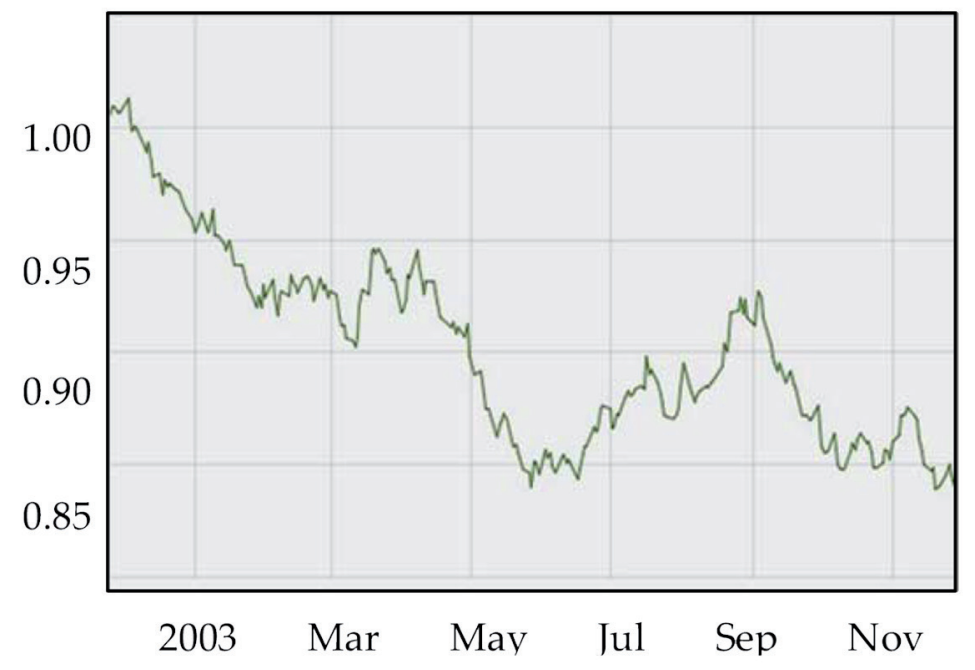

After that, the exposure of a highly probable predicted goods sale transaction to currency risk is measured. Then the exchange rate variability is assessed and the value at risk $(\mathrm{VaR})$ of the predicted goods sale transaction calculated. After calculating risk factors variability, it is necessary to specify the time period for which VaR is calculated. In this case it is 76 days. Annual variability $(\sigma)$ USD / EUR is calculated on the basis of its daily variability in the previous year according to the formula: $\sigma_{\text {annual }}=\sigma_{\text {periodic }} \times \sqrt{B P}$ - whereby: BP - denotes the number of periods taken into consideration: $\sigma=0.0064 \mathrm{x}=8.717797887=0.055793906$.

Finally, the rate of significance is determined. VaR is calculated with $95 \%$ significance (1.65 standard deviations). According to the general pattern, value at risk is calculated as the product of the value of the item at risk (VIR), variability of risk factors to which the item is exposed $(\sigma)$ and standard deviation (S) in accordance with the selected significance: $\mathrm{VaR}=$ VIR ${ }^{*} \sigma{ }^{*} S$ (Holton, Glyn, 2003), $\mathrm{VaR}=803,178.90 \times 0.055793906 \times$ $1.65=73,940.61 \mathrm{EUR}$. 
nula prihoda i ima samo vremensku vrednost. Istovremeno, ova opcija je u jakoj korelaciji sa vremenom preostalim do datuma dospeća. U kontekstu računovodstvenih pravila neophodno je unapred dokumentovati hedžing odnos. Preciznije, potrebno je pripremiti dokumentaciju iz koje su nedvosmisleno vidljivi sledeći elementi (Ramirez, 2007. str. 7): (1) ciljevi i namena zaštite; (2) štićena stavka, (3) instrument zaštite; (4) vrsta zaštite i (5) karakteristike predviđene transakcije.

Pre datuma dospeća neophodno je kontinuirano pratiti cenu valute, porediti neposrednu vrednost izvršenja opcije sa nerizičnom očekivanom vrednošću zadržavanja opcije i razmatrati da li je neposredno izvršenje opcije povoljnije. U kontekstu računovodstvenih pravila, takođe, treba definisati kriterijume za testiranje efektivnost hedžinga pojedinačno za svaki hedžing instrument i štićenu stavku. Kriterijumi MRS 39 za testiranje efektivnosti zaštite uključuju uslov da hedžing odnos mora da ispuni kvantitativni prag od 80$125 \%$ prospektivno i retrospektivno.

Tabela 3. Dokumentaciona osnova hedžinga

\begin{tabular}{|c|c|}
\hline \multicolumn{2}{|l|}{ INSTRUMENT ZA ZAŠTITU } \\
\hline Naziv finansijskog instrumenta & Evropska valutna (put) opcija \\
\hline Opis transakcije & Pravo prodaje USD za EUR \\
\hline Datum sklapanja & 26.11.2003. \\
\hline Datum dospeća & 14.03.2004. \\
\hline Izvršna cena & $1 \mathrm{EUR}=1,1828 \mathrm{USD}$ \\
\hline $\begin{array}{l}\text { Fer vrednost na dan zaključenja } \\
\text { valutnoopcijskog ugovora }\end{array}$ & 16.691,50 EUR \\
\hline \multicolumn{2}{|l|}{ ŠTIĆENA STAVKA } \\
\hline Period & 26.11.2003 - 17.02.2004. \\
\hline Predviđena transakcija & $\begin{array}{l}\text { Prodaja robe kupcu u inostranstvu } \\
\text { (transakcija izražena u EUR) }\end{array}$ \\
\hline Očekivano vreme realizacije & 17.02.2004. \\
\hline Iznos & $950.000,00$ USD \\
\hline Stopa sigurnosti realizacije & $97 \%$ \\
\hline Priznato sredstvo & Potraživanje od inostranog kupca \\
\hline Predviđena vrednost & $950.000,00$ USD \\
\hline \multicolumn{2}{|l|}{ RIZIK OD KOJEG SE ŠTITIMO } \\
\hline & $\begin{array}{l}\text { Rizik promene deviznog kursa } \\
\text { USD/EUR }\end{array}$ \\
\hline \multicolumn{2}{|l|}{ VRSTA ZAŠTITE } \\
\hline 26.11 .2003 - 17.02.2004. & $\begin{array}{l}\text { Zaštita novčanog toka predviđene } \\
\text { transakcije od rizika }\end{array}$ \\
\hline 17.02.2003 - 14.03.2004. & $\begin{array}{l}\text { Zaštita fer vrednosti priznatog } \\
\text { sredstva od rizika }\end{array}$ \\
\hline
\end{tabular}

Izvor: Autor

\section{Prospektivno testiranje efektivnosti zaštite}

$\mathrm{Na}$ osnovu regresione analize procenili smo smer kretanja hedžing odnosa u stvarnoj zaštiti u budućnosti nakon kupovine valutne opcije.

Tabela 4. (u Eur)

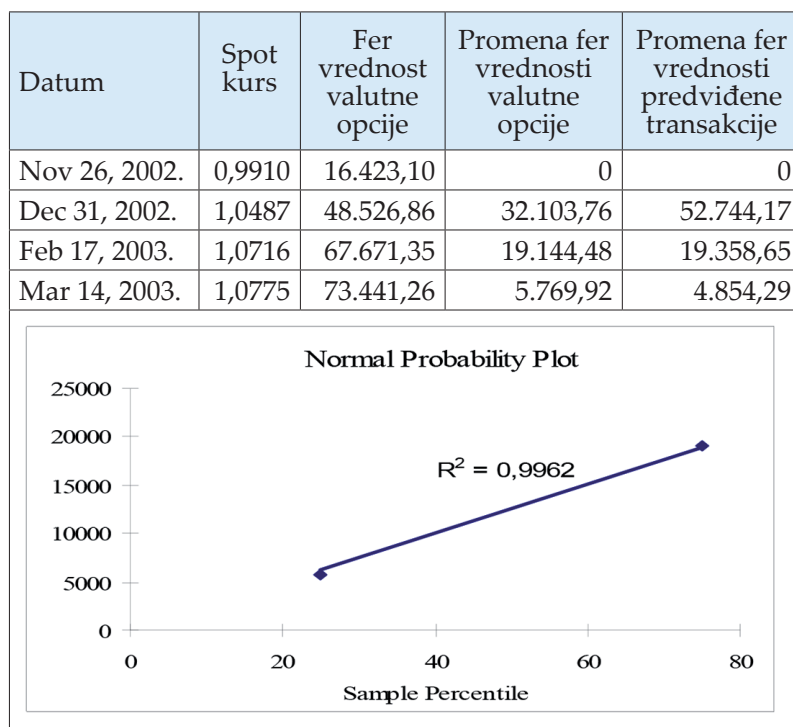

Izvor: Autor

Procenjuje se da će zaštita biti efektivna jer je korelacija promena fer vrednosti opcije i fer vrednosti predviđene transakcije visoka 0,997788868. Na dan bilansa treba izmeriti valutnu opciju. Fer vrednost se smatra najadekvatnijom merom za vrednovanje derivativnih instrumenata (Ramirez, 2008). Konkretno, MSFI 13 definiše fer vrednost kao cenu koja bi bila ostvarena prodajom neke stavke imovine ili plaćena za prenos neke obaveze $u$ urednoj transakciji među tržišnim učesnicima na datum merenja.

\section{Inicijalno knjiženje fer vrednosti valutne opcije}

Kupovina opcije za kupca predstavlja pravo koje se evidentira u sredstvima po fer vrednosti. Na dan 31.12.2003. vršimo priznavanje opcije u bilansu stanja. Ovde je njena fer vrednost jednaka plaćenoj premiji. 
Table 2. Value at risk (VaR) calculation

\begin{tabular}{|l|r|}
\hline Nominal value & $950,000.00$ USD \\
\hline $\begin{array}{l}\text { Spot exchange rate } \\
1 \text { EUR }=1,1828 \text { USD }\end{array}$ & $803,178.90$ EUR \\
\hline $\begin{array}{l}\text { Daily exchange rate } \\
\text { variability USD/EUR }\end{array}$ & $0.64 \%$ \\
\hline $\begin{array}{l}\text { The period of VaR } \\
\text { calculation }\end{array}$ & 110 days \\
\hline $\begin{array}{l}\text { The number of working } \\
\text { days }\end{array}$ & 76 \\
\hline Significance & $95 \%$ \\
\hline Value at risk (VaR) & $73,940.61 \mathrm{EUR}$ \\
\hline $\begin{array}{l}\text { The percentage of VaR in } \\
\text { the hedged item }\end{array}$ \\
\hline Source: Author
\end{tabular}

Given the high variability of the USD / EUR exchange rate and value at risk, the decision was made to hedge the predicted goods sale transaction against the currency risk. An agreement was made on the European putoption that would grant the right to sell $\$ 950,000.00$ on March 14, 2004 after the collection of receivables at the rate applicable on November 26, 2003, the date of signing of the contract. To be more precise, the "at-the-money" option was signed, which in the case of immediate execution leads to a zero income and has time value only. At the same time, this option is strongly correlated with the time remaining to maturity. In the context of accounting rules it is necessary to document the hedging relationship in advance. More specifically, it is necessary to prepare the documents that clearly demonstrate the following elements (Ramirez, 2007, p. 7): (1) the objectives and purposes of hedging; (2) the hedged item (3) the hedging instrument; (4) the type of hedging and (5) the characteristics of the predicted transaction.

Before maturity date it is necessary to continually monitor the currency price, compare the immediate value of the option exercise with the expected risk-free value of holding the option, and consider whether the direct exercise of the option is more favorable. In the context of accounting rules it is also necessary to define the criteria for hedge effectiveness testing for each hedging instrument and each hedged item individually. The IAS 39 criteria for testing the hedging effectiveness include the requirement that the hedging relationship should meet the quantitative threshold of $80-125 \%$ prospectively and retrospectively.
Table 3. Hedging documentation basis

\begin{tabular}{|l|l|}
\hline Hedging instrument & European currency (put) option \\
\hline $\begin{array}{l}\text { The name of the financial } \\
\text { instrument }\end{array}$ & The right to sell USD for EUR \\
\hline Transaction description & November 26, 2003 \\
\hline $\begin{array}{l}\text { The date of signing an } \\
\text { arrangement }\end{array}$ & March 14, 2004 \\
\hline Maturity date & 1 EUR =1.1828 USD \\
\hline The exercise price & $16,691.50$ EUR \\
\hline $\begin{array}{l}\text { Fair value on the date of signing } \\
\text { the currency option contract }\end{array}$ & 26.11.2003 - 17.02.2004 \\
\hline The hedged item & $\begin{array}{l}\text { Selling goods to a foreign buyer } \\
\text { (transaction recorded in EUR) }\end{array}$ \\
\hline Period & 17.02 .2004 \\
\hline Predicted transaction & $950,000.00$ USD \\
\hline The expected realization time & $97 \%$ \\
\hline Amount & Claims from a foreign buyer \\
\hline The rate of realization security & $950,000.00$ USD \\
\hline The accepted mechanism & $\begin{array}{l}\text { The risk against the change in } \\
\text { USD/EUR exchange rate }\end{array}$ \\
\hline The predicted value & $\begin{array}{l}\text { The predicted transaction cash } \\
\text { flow hedging against risk }\end{array}$ \\
\hline THE RISK THAT WE HEDGE AGAINST & $\begin{array}{l}\text { The accepted mechanism fair } \\
\text { value hedging against risk }\end{array}$ \\
\hline \multicolumn{2}{|l|}{}
\end{tabular}

Source: The author

\section{Prospective testing of hedging effectiveness}

Based on regression analysis, we estimated the direction of hedging relationship in the real protection in the future after the currency options are purchased.

Table 4. (in EUR)

\begin{tabular}{|l|r|r|r|r|}
\hline Date & \multicolumn{1}{|c|}{$\begin{array}{c}\text { Spot } \\
\text { exchange } \\
\text { rate }\end{array}$} & $\begin{array}{c}\text { Currency } \\
\text { option fair } \\
\text { value }\end{array}$ & $\begin{array}{c}\text { Currency } \\
\text { option } \\
\text { fair value } \\
\text { change }\end{array}$ & $\begin{array}{c}\text { Predicted } \\
\text { transaction } \\
\text { fair value } \\
\text { change }\end{array}$ \\
\hline Nov 26, 2002 & 0,9910 & $16.423,10$ & 0 & 0 \\
\hline Dec 31, 2002 & 1,0487 & $48.526,86$ & $32.103,76$ & $52.744,17$ \\
\hline Feb 17, 2003 & 1,0716 & $67.671,35$ & $19.144,48$ & $19.358,65$ \\
\hline Mar 14, 2003 & 1,0775 & $73.441,26$ & $5.769,92$ & $4.854,29$ \\
\hline
\end{tabular}

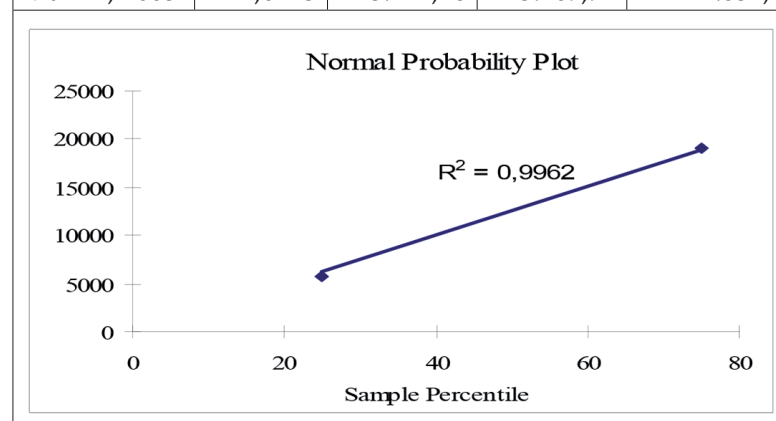

Izvor: Autor 
Tabela 5. (u Eur)

\begin{tabular}{|c|c|c|c|}
\hline R. br. & Opis & Duguje & Potražuje \\
\hline \multirow[b]{2}{*}{1.} & Opcija & $16.691,50$ & \\
\hline & $\begin{array}{l}\text { Tekući (poslovni) } \\
\text { račun }\end{array}$ & & $16.691,50$ \\
\hline
\end{tabular}

Izvor: Autor

Na bilansni dan vršimo naknadno merenje opcije. U ovom slučaju, poslovna i kalendarska godina se poklapaju. Na kotiranom tržištu fer vrednost opcije na dan 31.12.2003. iznosila je 52.269,76 EUR. Sada, fer vrednost opcije treba razdeliti na intrinsičnu i vremensku komponentu. Intrinsična vrednost opcije predstavlja razliku između izvršnog i spot kursa a vremenska vrednost je rezidualna razlika između ukupne fer vrednosti opcije i njene intrinsične vrednosti. Promena vrednosti opcije je izračunata kao razlika između njene vrednosti na dan 31.12.2003. i vrednosti na dan 26.11.2003. koji je priznat u kapitalu po osnovu zaštite $\mathrm{u}$ napomenama uz izveštaj o ostalom rezultatu,

- iznos koji je priznat po osnovu vremenske vrednosti opcije treba obelodaniti $u$ napomenama uz bilans uspeha,

- fer vrednost opcije se obelodanjuje u napomenama uz bilans stanja - finansijska ulaganja. Osim toga obelodanićemo karakteristike predviđene transakcije prodaje robe i vremenski period $\mathrm{u}$ kojem se očekuje njena realizacija kao i predviđeni iznos, i

- informacije o izabranom modelu merenja fer vrednosti opcije, u ovom slučaju kotirana cena na aktivnom tržištu.

Naravno, pravilnikom o računovodstvu se određuje i materijalnost stavki kod obelodanjivanja. To je prag kod kojeg aspekti postaju dovoljno važni da bi se o njima trebalo izveštavati.
Tabela 6. (u Eur)

\begin{tabular}{|l|c|r|r|r|r|r|}
\hline Datum & $\begin{array}{c}\text { Fer } \\
\text { vrednost } \\
\text { valutne } \\
\text { opcije }\end{array}$ & $\begin{array}{c}\text { Intrinsična } \\
\text { vrednost } \\
\text { valutne } \\
\text { opcije }\end{array}$ & $\begin{array}{c}\text { Vremenska } \\
\text { vrednost } \\
\text { valutne } \\
\text { opcije }\end{array}$ & $\begin{array}{c}\text { Promena } \\
\text { intrinsične } \\
\text { vrednosti } \\
\text { valutne } \\
\text { opcije }\end{array}$ & $\begin{array}{c}\text { Promena } \\
\text { vremenske } \\
\text { vrednosti } \\
\text { valutne } \\
\text { opcije }\end{array}$ & $\begin{array}{c}\text { Promena } \\
\text { fer } \\
\text { vrednosti } \\
\text { valutne } \\
\text { opcije }\end{array}$ \\
\hline 26.11 .2003$. & $16.691,50$ & 0 & $16.691,50$ & 0 & 0 & 0 \\
\hline 31.12 .2003$. & $52.269,76$ & $51.001,54$ & $1.268,22$ & $51.001,54$ & $-15.423,28$ & $35.578,26$ \\
\hline
\end{tabular}

Izvor: Autor

Vršimo ispravku knjigovodstvene vrednosti opcije za iznos promene njene fer vrednosti i priznavanje promene intrinsične vrednosti $u$ kapitalu a promenu vremenske vrednosti $\mathrm{u}$ poslovnom rezultatu.

Tabela 7. (u Eur)

\begin{tabular}{|l|l|c|c|}
\hline \multirow{2}{*}{ R. br. } & Opis & Duguje & Potražuje \\
\hline \multirow{3}{*}{2.} & Opcija & $35.578,26$ & \\
\cline { 2 - 4 } & Finansijski rashodi & $15.423,28$ & \\
\cline { 2 - 4 } & Hedž rezerve & & $51.001,54$ \\
\hline
\end{tabular}

Izvor: Autor

\section{Obelodanjivanja $\mathbf{u}$ finansijskim izveštajima}

U finansijskim izveštajima treba obelodaniti sledeće informacije:

- karakteristike hedžing odnosa u poglavlju o upravljanju finansijskim rizicima a iznos
Priznavanje štićene stavke i postupak knjiženja

Pošto je na dan 17.02.2004. realizovan predviđeni izvoz robe $\mathrm{u}$ vrednosti od 950.000,00 USD, na taj datum vršimo priznavanje prihoda od prodaje i potraživanja od kupaca u inostranstvu.

Tabela 8.

\begin{tabular}{|l|c|}
\hline Datum & Spot kurs \\
\hline Nov 26, 2003. & 1 EUR $=1,1828$ USD \\
\hline Dec 31, 2003. & 1 EUR $=1,2630$ USD \\
\hline Feb 17, 2004. & 1 EUR $=1,2858$ USD \\
\hline
\end{tabular}

Izvor: European Central Bank

Priznajemo štićenu stavku iskazanu u EUR po srednjem kursu European Central Bank 17.02.2004. godine.

Tabela 9. (u Eur)

\begin{tabular}{|l|l|c|c|}
\hline R. br. & Opis & Duguje & Potražuje \\
\hline 3. & $\begin{array}{l}\text { Potraživanja } \\
\text { od kupaca u } \\
\text { inostranstvu }\end{array}$ & $738.839,63$ & \\
\hline & Prihodi od prodaje & & $738.839,63$ \\
\hline
\end{tabular}

Izvor: Autor 
It is estimated that the hedging will be effective because the correlation between the fair value option change and the fair value of the predicted transaction is high - 0.997788868 . Currency option should be measured on the date of the balance. Fair value is considered to be the most appropriate measure for evaluating derivative instruments (Ramirez, 2008). In particular, IFRS 13 defines fair value as the price that would be realized by selling an asset or paid to transfer a liability in an orderly transaction between market participants at the measurement date.

\section{The initial accounting entry of currency option fair value}

Purchasing an option represents the right for the buyer that is recorded in the assets at fair value. On December 31, 2003 the option was recognized in the balance sheet. Here its fair value is equal to the premium paid.

\section{Table 5. (in EUR)}

\begin{tabular}{|l|l|c|c|}
\hline No. & Description & Liabilities & Claims \\
\hline \multirow{2}{*}{1.} & Option & $16,691.50$ & \\
\cline { 2 - 4 } & $\begin{array}{l}\text { Current (business) } \\
\text { account }\end{array}$ & & $16,691.50$ \\
\hline
\end{tabular}

Source: Author

On the balance day the subsequent option measurement was made. In this case, the business and calendar year coincide. In the quoted market the option fair value on December 31, 2003 amounted to $€$ 52,269.76. Now, the option fair value should be divided into the intrinsic and time component. The option intrinsic value is the difference between the execution and spot exchange rate, while the time value is the residual difference between the total option fair value and its intrinsic value. The option value change is calculated as the difference between its value on December 31, 2003 and the value on November 26, 2003.

Table 6. (in EUR)

\begin{tabular}{|l|l|r|r|r|r|r|}
\hline Date & $\begin{array}{l}\text { Currency } \\
\text { option } \\
\text { fair value }\end{array}$ & $\begin{array}{c}\text { Currency } \\
\text { option } \\
\text { intrinsic } \\
\text { value }\end{array}$ & $\begin{array}{c}\text { Currency } \\
\text { option } \\
\text { time } \\
\text { value }\end{array}$ & $\begin{array}{c}\text { Currency } \\
\text { option } \\
\text { intrinsic } \\
\text { value } \\
\text { change }\end{array}$ & $\begin{array}{c}\text { Currency } \\
\text { option } \\
\text { time } \\
\text { value } \\
\text { change }\end{array}$ & $\begin{array}{c}\text { Currency } \\
\text { option } \\
\text { fair value } \\
\text { change }\end{array}$ \\
\hline 26.11 .2003 & $16,691.50$ & 0 & $16,691.50$ & 0 & 0 & 0 \\
\hline 31.12 .2003 & $52,269.76$ & $51,001.54$ & $1,268.22$ & $51,001.54$ & $-15,423.28$ & $35,578.26$ \\
\hline
\end{tabular}

Source: The author
The correction of the book value of the option was made in the amount of its fair value change, while the intrinsic value change of equity and the time value change in business result were recognized.

\section{Table 7. (in EUR)}

\begin{tabular}{|c|c|c|c|}
\hline No & Description & Liabilities & Claims \\
\hline \multirow{3}{*}{2.} & Option & $35,578.26$ & \\
\hline & Financing costs & $15,423.28$ & \\
\hline & Hedging reserves & & $51,001.54$ \\
\hline
\end{tabular}

Source: Author

\section{Disclosures in the Financial Statements}

The following information should be disclosed in financial statements:

- characteristics of the hedging relationship in the chapter on managing financial risks, and the amount recognized in equity on the basis of hedging should be in the notes accompanying the Statement of Other Comprehensive Result,

- the amount recognized on the basis of the option time value should be disclosed in the notes accompanying Income Statement,

- fair value of the option is disclosed in the notes accompanying the Balance Sheet - Financial Investments. In addition, the characteristics of the predicted transaction of goods sale will also be disclosed, as well as the time period in which its realization is expected and the anticipated amount,

- information on the chosen model of option fair value measuring, in this case the quoted price in an active market.

Of course, the Rulebook on Accounting determines the material side of items on disclosure. This is the threshold at which the items become important enough to be reported on.

\section{Recognition of a hedged item and} the accounting entry procedure

Given that on February 17, 2004 the intended export of goods worth $\$ 950,000.00$ was realized, as of that date

Source: The author 
Na dan realizacije predviđene transakcije prodaje robe 17.02.2004. vršimo naknadno merenje opcije i prenos akumuliranog iznosa iz kapitala u poslovni rezultat. Fer vrednost opcije na kotiranom tržištu sada iznosi 64.559,10 EUR. Ovde, fer vrednost opcije ponovo razdvajamo na intrinsičnu i vremensku komponentu.

Tabela 10. (u Eur)

\begin{tabular}{|l|c|r|r|r|r|r|}
\hline Datum & $\begin{array}{c}\text { Fer } \\
\text { vrednost } \\
\text { valutne } \\
\text { opcije }\end{array}$ & $\begin{array}{c}\text { Intrinsična } \\
\text { vrednost } \\
\text { valutne } \\
\text { opcije }\end{array}$ & $\begin{array}{c}\text { Vremenska } \\
\text { vrednost } \\
\text { valutne } \\
\text { opcije }\end{array}$ & $\begin{array}{c}\text { Promena } \\
\text { intrinsične } \\
\text { vrednosti } \\
\text { valutne } \\
\text { opcije }\end{array}$ & $\begin{array}{c}\text { Promena } \\
\text { vremenske } \\
\text { vrednosti } \\
\text { valutne } \\
\text { opcije }\end{array}$ & $\begin{array}{c}\text { Promena } \\
\text { fer } \\
\text { vrednosti } \\
\text { valutne } \\
\text { opcije }\end{array}$ \\
\hline 26.11.2003. & $16.691,50$ & 0 & $16.691,50$ & 0 & 0 & 0 \\
\hline 31.12 .2003$. & $52.269,76$ & $51.001,54$ & $1.268,22$ & $51.001,54$ & $-15.423,28$ & $35.578,26$ \\
\hline 17.02 .2004$. & $64.559,10$ & $64.339,26$ & 219,84 & $13.337,72$ & $-1.048,38$ & $12.289,34$ \\
\hline
\end{tabular}

\section{Knjiženje}

Korigujemo knjigovodstvenu vrednost opcije i time iskažemo promenu fer vrednosti u periodu od 31.12. do 17.02. Kao na dan bilansa, izvršićemo priznavanje promene intrinsične vrednosti opcije $\mathrm{u}$ kapitalu a promene vremenske vrednosti opcije u poslovnom rezultatu.

Tabela 11. (u Eur)

\begin{tabular}{|l|l|c|c|}
\hline R. br. & Opis & \multicolumn{1}{|c|}{ Duguje } & Potražuje \\
\hline 4. & Opcija & $12.289,34$ & \\
\hline & Finansijski rashodi & $1.048,38$ & \\
\hline & Hedž rezerve & & $13.337,72$ \\
\hline
\end{tabular}

Izvor: Autor

\section{Knjiženje}

Realizacija predviđene transakcije prodaje robe $\mathrm{u}$ celosti je uticala na poslovni rezultat subjekta. Stoga moramo izvršiti prenos ukupnog iznosa iz kapitala u poslovni rezultat.

Tabela 12. (u Eur)

\begin{tabular}{|l|l|c|c|}
\hline R. br. & Opis & Duguje & Potražuje \\
\hline 5. & Ispravka kapitala & & $-64.339,26$ \\
\hline & Finansijski prihodi & & $64.339,26$ \\
\hline
\end{tabular}

Izvor: Autor

Na dan 14.03.2004. inostrani kupac je izmirio svoju obavezu. Kako je spot devizni kurs viši od izvršnog opcija će se realizovati.
Tabela 13.

\begin{tabular}{|l|l|}
\hline Datum & Spot kurs \\
\hline Nov 26, 2003. & 1 EUR $=1,1828$ USD \\
\hline Dec 31, 2003. & 1 EUR $=1,2630$ USD \\
\hline Feb 17, 2004. & 1 EUR $=1,2858$ USD \\
\hline Mar 14, 2004. & 1 EUR $=1,2235$ USD \\
\hline
\end{tabular}

Izvor: European Central Bank

Prema ugovoru 14.03.2004. inostrani kupac je izvršio uplatu u iznosu od 950.000,00 USD. Ovu uplatu treba evidentirati u EUR po srednjem kursu European Central Bank.

\section{Knjiženje}

Tabela 14. (u Eur)

\begin{tabular}{|l|l|c|c|}
\hline R. br. & Opis & Duguje & Potražuje \\
\hline 6. & $\begin{array}{l}\text { Tekući } \\
\text { (poslovni) račun }\end{array}$ & $776.460,97$ & \\
\hline & $\begin{array}{l}\text { Potraživanja } \\
\text { od kupaca u } \\
\text { inostranstvu }\end{array}$ & $776.460,97$ \\
\hline
\end{tabular}

Izvor: Autor

\section{Naknadno merenje potraživanja od kupaca i postupak knjiženja}

Izvršićemo naknadno merenje potraživanja od kupaca u inostranstvu i iskazati promenu fer vrednosti u poslovnom rezultatu.

Tabela 15. (u Eur)

\begin{tabular}{|l|l|c|c|}
\hline R. br. & Opis & Duguje & Potražuje \\
\hline 7. & $\begin{array}{l}\text { Potraživanja } \\
\text { od kupaca u } \\
\text { inostranstvu }\end{array}$ & $37.621,34$ & \\
\hline & Finansijski prihodi & & $37.621,34$ \\
\hline
\end{tabular}

Izvor: Autor

\section{Izvršenje valutne opcije i postupak knjiženja}

$\mathrm{Na}$ dan 14.03.2004. opcija se realizuje obzirom da je spot devizni kurs viši od izvršnog, odnosno, kupiće se određeni iznos deviza po izvršnom deviznom kursu. Na taj datum fer vrednost opcije je jednaka intrinsičnoj vrednosti a vremenska vrednost je nula. 
the revenues from sales and receivables from a foreign buyer are recognized.

Table 8 .

\begin{tabular}{|l|r|}
\hline Date & Spot exchange rate \\
\hline Nov 26, 2003 & 1 EUR=1.1828 USD \\
\hline Dec 31, 2003 & 1 EUR $=1.2630$ USD \\
\hline Feb 17, 2004 & 1 EUR $=1.2858$ USD \\
\hline
\end{tabular}

Source: European Central Bank

The hedged item expressed in EUR at the middle exchange rate of European Central Bank on February 17, 2004 is recognized.

\section{Table 9. (in EUR)}

\begin{tabular}{|l|l|c|c|}
\hline No & Description & Liabilities & Claims \\
\hline 3. & $\begin{array}{l}\text { Claims from } \\
\text { foreign buyers }\end{array}$ & $738,839.63$ & \\
\hline & Revenue from sales & & $738,839.63$ \\
\hline
\end{tabular}

Source: Author

On the day of the execution of the goods sale transaction, February 17, 2004, the subsequent option measurement and transfer of the accumulated amount from equity to operating result was performed. The option fair value on the quoted market now amounts to $€ 64,559.10$. Here, the option fair value is again separated into the intrinsic and time component.

\section{Accounting entry}

The accounting value of the option is adjusted and thus the change in fair value declared in the period from December 31 to February 17. Like on the Balance sheet day, the change of the option intrinsic value in equity was recognized, as well as the change of the option time value in the business result.

Table 11. (in EUR)

\begin{tabular}{|l|l|r|r|}
\hline No & Description & Liabilities & Claims \\
\hline 4. & Option & $12,289.34$ & \\
\hline & Financing costs & $1,048.38$ & \\
\hline & Hedging reserve & & $13,337.72$ \\
\hline
\end{tabular}

Source: Author

\section{Accounting entry}

The realization of the predicted transactions of goods sale completely influenced the business result of the entity. Therefore, the transfer of the total amount from equity to the operating result had to be performed.

Table 12. (in EUR)

\begin{tabular}{|l|l|l|l|}
\hline No & Description & Liabilities & \multicolumn{1}{c|}{ Claims } \\
\hline 5. & $\begin{array}{l}\text { Correction in } \\
\text { equity }\end{array}$ & & $-64,339.26$ \\
\hline & Financial revenue & & $64,339.26$ \\
\hline
\end{tabular}

Source: Author

Table 10. (in EUR)

\begin{tabular}{|l|r|r|r|r|r|r|}
\hline Date & $\begin{array}{c}\text { Currency } \\
\text { option } \\
\text { fair } \\
\text { value }\end{array}$ & $\begin{array}{c}\text { Currency } \\
\text { option } \\
\text { intrinsic } \\
\text { value }\end{array}$ & $\begin{array}{c}\text { Currency } \\
\text { option time } \\
\text { value }\end{array}$ & $\begin{array}{c}\text { Currency } \\
\text { option } \\
\text { intrinsic } \\
\text { value } \\
\text { change }\end{array}$ & $\begin{array}{c}\text { Currency } \\
\text { option } \\
\text { time value } \\
\text { change }\end{array}$ & $\begin{array}{c}\text { Currency } \\
\text { option } \\
\text { fair value } \\
\text { change }\end{array}$ \\
\hline 26.11 .2003 & $16,691.50$ & 0 & $16,691.50$ & 0 & 0 & 0 \\
\hline 31.12 .2003 & $52,269.76$ & $51,001.54$ & $1,268.22$ & $51,001.54$ & $-15,423.28$ & $35,578.26$ \\
\hline 17.02 .2004 & $64,559.10$ & $64,339.26$ & 219.84 & $13,337.72$ & $-1,048.38$ & $12,289.34$ \\
\hline
\end{tabular}

On March 14, 2004 the foreign buyer settled his obligation. As the spot exchange rate is higher than the exercise rate, the option will be exercised. 
Tabela 16. (u Eur)

\begin{tabular}{|l|r|r|r|r|r|r|}
\hline Datum & \multicolumn{1}{|c|}{$\begin{array}{c}\text { Fer vrednost } \\
\text { valutne opcije }\end{array}$} & $\begin{array}{c}\text { Intrinsična } \\
\text { vrednost } \\
\text { valutne opcije }\end{array}$ & $\begin{array}{c}\text { Vremenska } \\
\text { vrednost } \\
\text { valutne opcije }\end{array}$ & $\begin{array}{c}\text { Promena } \\
\text { intrinsične } \\
\text { vrednosti } \\
\text { valutne opcije }\end{array}$ & $\begin{array}{c}\text { Promena } \\
\text { vremenske } \\
\text { vrednosti } \\
\text { valutne opcije }\end{array}$ & $\begin{array}{c}\text { Promena fer } \\
\text { vrednosti } \\
\text { valutne opcije }\end{array}$ \\
\hline 26.11.2003. & $16.691,50$ & 0 & $16.691,50$ & 0 & 0 & 0 \\
\hline 31.12 .2003$. & $52.269,76$ & $51.001,54$ & $1.268,22$ & $51.001,54$ & $-15.423,28$ & $35.578,26$ \\
\hline 17.02 .2004$. & $64.559,10$ & $64.339,26$ & 219,84 & $13.337,72$ & $-1.048,38$ & $12.289,34$ \\
\hline 14.03 .2004$. & $26.717,92$ & $26.717,92$ & 0 & $-37.621,34$ & 219,84 & $-37.841,18$ \\
\hline
\end{tabular}

Izvor: Autor

\section{Knjiženje}

Tabela 17. (u Eur)

\begin{tabular}{|l|l|c|r|}
\hline R. br. & Opis & Duguje & Potražuje \\
\hline 8. & $\begin{array}{l}\text { Tekući (poslovni) } \\
\text { račun }\end{array}$ & $803.178,90$ & \\
\hline & $\begin{array}{l}\text { Tekući (poslovni) } \\
\text { račun }\end{array}$ & & $776.460,98$ \\
\hline & Opcija & & $26.717,92$ \\
\hline
\end{tabular}

Izvor: Autor

\section{Priznavanje promene fer vrednosti opcije i štićene stavke}

Vršimo naknadno merenje opcije i promenu fer vrednosti iskazujemo $u$ poslovnom rezultatu. Da podsetimo, u periodu od 17.02. do 14.03. štitili smo fer vrednost priznatog sredstva od valutnog rizika. Stoga vršimo priznavanje promene fer vrednosti opcije i štićene stavke u poslovnom rezultatu.

Tabela 18. (u Eur)

\begin{tabular}{|l|l|c|c|}
\hline R. br. & Opis & Duguje & Potražuje \\
\hline 9. & $\begin{array}{l}\text { Finansijski } \\
\text { rashodi }\end{array}$ & $37.841,18$ & \\
\hline & Opcija & & $37.841,18$ \\
\hline
\end{tabular}

Izvor: Autor

Po završetku zaštite vršimo procenu njene efektivnosti od 17.02. do 14.03.2004. $\mathrm{Na}$ osnovu dobijenog rezultata od 99,42\% možemo da konstatujemo da je zaštita bila efektivna. Preciznije, hedžing odnos ispunjava kvantitativni prag od $80-125 \%$ retrospektivno.
Tabela 19. (u Eur)

\begin{tabular}{|l|r|}
\hline Promena fer vrednosti opcije & $37.841,18$ \\
\hline Promena fer vrednosti potraživanja & $37.621,34$ \\
\hline Rezultat: & $99,42 \%$ \\
\hline
\end{tabular}

Izvor: Autor

Da zaštita od valutnog rizika nije korišćena uticaj predviđene transakcije a nakon toga priznatog potraživanja bio bi sledeći:

Tabela 20. (u Eur)

\begin{tabular}{|l|l|r|}
\hline Datum & Stavka & \multicolumn{1}{|c|}{ Iznos } \\
\hline 17.02.2004. & Prihodi od prodaje & $738.839,63$ \\
\hline 14.03.2004. & Pozitivne kursne razlike & $37.621,34$ \\
\hline & Total : & $776.460,97$ \\
\hline
\end{tabular}

Može se zaključiti da je do pozitivnih kursnih razlika došlo usled promene deviznog kursa u periodu od 17.02. kada je priznato potraživanje od kupca u inostranstvu do 14.03.2004. kada je izvršeno plaćanje. Otuda, očigledno je da je subjekt ostvario dodatnu korist po osnovu izvozne transakcije. Međutim, posmatrano kroz prizmu promene deviznog kursa $\mathrm{u}$ periodu od 31.12. do 14.03.2004. vidi se da je priznavanje pozitivnih kursnih razlika rezultat visoke varijabilnosti USD u tom periodu. Iako je poslovni rezultat izložen variranju, zaštitom od nepovoljnog kretanja deviznog kursa postignuto je ostvarenje planiranog poslovnog rezultata. 
Table 13.

\begin{tabular}{|l|r|}
\hline Date & Spot exchange rate \\
\hline Nov 26, 2003 & 1 EUR=1.1828 USD \\
\hline Dec 31, 2003 & 1 EUR=1.2630 USD \\
\hline Feb 17, 2004 & 1 EUR=1.2858 USD \\
\hline Mar 14, 2004 & 1 EUR $=1.2235$ USD \\
\hline
\end{tabular}

Source: European Central Bank

Under the contract as of March 14, 2004, the foreign buyer made the payment in the amount of $\$ 950,000.00$. This payment should be recorded in Euros at the middle exchange rate of the European Central Bank.

\section{Accounting entry}

Table 14. (in EUR)

\begin{tabular}{|l|l|l|c|}
\hline No & Description & Liabilities & Claims \\
\hline 6. & $\begin{array}{l}\text { Current (business) } \\
\text { account }\end{array}$ & $776,460.97$ & \\
\hline & $\begin{array}{l}\text { Claims from foreign } \\
\text { buyers }\end{array}$ & & $776,460.97$ \\
\hline
\end{tabular}

Source: Author

\section{Subsequent measurement of trade receivables and the accounting entry procedure}

Subsequent measurement of receivables from foreign buyers will be made and the change in fair value declared in the business result.

Table 15. (u Eur)

\begin{tabular}{|l|l|c|c|}
\hline No & Description & Liabilities & Claims \\
\hline 7. & $\begin{array}{l}\text { Claims from } \\
\text { foreign buyers }\end{array}$ & $37,621.34$ & \\
\hline & Financial revenue & & $37,621.34$ \\
\hline
\end{tabular}

Source: Author

\section{Exercising of currency options and the accounting entry procedure}

On March 14, 2004 the option was exercised, given that the spot exchange rate was higher than the exercise rate, i.e., a certain amount of foreign currency was to be bought at the exercise exchange rate. On that date the option fair value would be equal to the intrinsic value, while the time value would equal zero.

Table 16. (in EUR)

\begin{tabular}{|l|r|r|r|r|r|r|}
\hline Date & \multicolumn{1}{|c|}{$\begin{array}{c}\text { Currency } \\
\text { option fair } \\
\text { value }\end{array}$} & $\begin{array}{c}\text { Currency } \\
\text { option intrinsic } \\
\text { value }\end{array}$ & \multicolumn{1}{c|}{$\begin{array}{c}\text { Currency } \\
\text { option time } \\
\text { value }\end{array}$} & $\begin{array}{c}\text { Currency } \\
\text { option intrinsic } \\
\text { value change }\end{array}$ & \multicolumn{1}{c|}{$\begin{array}{c}\text { Currency } \\
\text { option time } \\
\text { value change }\end{array}$} & $\begin{array}{c}\text { Currency } \\
\text { option fair } \\
\text { value change }\end{array}$ \\
\hline 26.11 .2003 & $16,691.50$ & 0 & $16,691.50$ & 0 & 0 & 0 \\
\hline 31.12 .2003 & $52,269.76$ & $51,001.54$ & $1,268.22$ & $51,001.54$ & $-15,423.28$ & $35,578.26$ \\
\hline 17.02 .2004 & $64,559.10$ & $64,339.26$ & 219.84 & $13,337.72$ & $-1,048.38$ & $12,289.34$ \\
\hline 14.03 .2004 & $26,717.92$ & $26,717.92$ & 0 & $-37,621.34$ & 219.84 & $-37,841.18$ \\
\hline
\end{tabular}




Tabela 21.
\begin{tabular}{|l|l|r|l|}
\hline 31.12 .2003$. & Finansijski rashodi & $-15.423,28$ & Vremenska vrednost opcije \\
\hline 17.02 .2004$. & Finansijski rashodi & $-1.048,38$ & Vremenska vrednost opcije \\
\hline 17.02 .2004$. & Finansijski rashodi & $64.339,26$ & Intrinsična vrednost opcije \\
\hline 17.02 .2004$. & Prihodi od prodaje & $738.839,63$ & Prodaja stranom kupcu \\
\hline 14.03 .2004$. & Finansijski prihodi & $37.621,34$ & Fer vrednost potraživanja \\
\hline 14.03 .2004$. & Finansijski rashodi & $-37.841,18$ & Fer vrednost opcije \\
\hline & Total: & $786.487,39$ & \\
\hline
\end{tabular}

Izvor: Autor

Kao što pokazuje tabela 21. vrednost transakcije je zaštićena na iznos od 786.487,39 EUR bez obzira na tržišno pomeranje kursa. To odgovara ugovorenom izvršnom kursu umanjeno za iznos plaćene premije (803.178,90 - 16.691,50 = 786.487,40). Otuda, jasno se može zaključiti da je stabilnost poslovanja ostala nenarušena.

\section{Zaključak}

Opcije kao finansijski derivati su jedna od najzahtevnijih finansijskih formi uopšte. Primena opcija zahteva mnogo znanja, $u$ suprotnom, umesto $\mathrm{u}$ prave svrhe njihova upotreba može da se pretvori u poslovnu katastrofu.

Opcije su veoma interesantni finansijski derivati koji imaocu nude niz mogućnosti i prednosti, ali zbog svoje kompleksnosti i nerazvijenog tržišta na ovim prostorima ipak su zapostavljene. Šira primena valutnih opcija svakako nije moguća bez postojanja dostupnog, širokog i likvidnog tržišta finansijskih derivata. Činjenica je da Srbija zaostaje za razvojem finansijskih derivata i da u ovoj oblasti ostaje mnogo toga da se uradi. Svetska ekonomija se globalizuje i srpska ekonomija zbog svoje male veličine neće moći još dugo da bude izolovano ostrvo usred glavnih ekonomskih tokova.

Za uspešnu primenu valutnih opcija $u$ zaštiti od valutnog rizika, potrebno je poznavati njihovu prirodu, usvojiti savremena znanja, proučavati standarde koji regulišu njihov računovodstveni tretman, unaprediti ponudu derivata i intenzivirati sve oblike edukacije o zaštiti od valutnog rizika. Tim pre što razvoj finansijskih derivata koji se očekuje pre ili kasnije svi subjekti u Srbiji trebaju da dočekaju spremni. 


\section{Accounting entry}

Table 17. (in EUR)

\begin{tabular}{|l|l|c|c|}
\hline No & Description & Liabilities & Claims \\
\hline 8. & $\begin{array}{l}\text { Current (business) } \\
\text { account }\end{array}$ & $803,178.90$ & \\
\hline & $\begin{array}{l}\text { Current (business) } \\
\text { account }\end{array}$ & & $776,460.98$ \\
\hline & Option & & $26,717.92$ \\
\hline
\end{tabular}

Source: Author

\section{Recognition of the fair value change of options and hedged items}

The subsequent measurement of the option was performed and the fair value change recorded in business results. Let us remind the reader that in the period from February 17 to March 14 the fair value of the recognized asset was hedged against the currency risk. Therefore, the option fair value change and the hedged item change were recognized in the operational result.

Table 18. (in EUR)

\begin{tabular}{|l|l|r|r|}
\hline No & Description & Liabilities & Claims \\
\hline 9. & $\begin{array}{l}\text { Financing } \\
\text { costs }\end{array}$ & $37,841.18$ & \\
\hline & Option & & $37,841.18$ \\
\hline
\end{tabular}

Source: Author

Upon completing the hedging its effectiveness from February 17 to March 14, 2004 is estimated. Based on the obtained result of $99.42 \%$ it can be concluded that the hedging was effective. More precisely, the hedging relationship meets the quantitative threshold of $80-125 \%$ retrospectively.
Table 19. (in EUR)

\begin{tabular}{|l|r|}
\hline Option fair value change & $37,841.18$ \\
\hline Claims fair value chnage & $37,621.34$ \\
\hline Result: & $99.42 \%$ \\
\hline
\end{tabular}

Source: Author

If hedging against currency risk had not been used, the influence of a predicted transaction, and subsequently recognized claims would be as follows:

Table 20. (in EUR)

\begin{tabular}{|l|l|r|}
\hline Date & \multicolumn{1}{|c|}{ Item } & \multicolumn{1}{c|}{ Amount } \\
\hline 17.02 .2004 & Revenue froma sales & $738,839.63$ \\
\hline 14.03.2004 & $\begin{array}{l}\text { Positive exchange rate } \\
\text { differences }\end{array}$ & $37,621.34$ \\
\hline & Total : & $776,460.97$ \\
\hline
\end{tabular}

Source: Author

It can be concluded that the positive exchange rate differences occurred due to the changes in the exchange rate in the period from February 17, when claims from foreign buyers were recognized until March 14, 2004, when the payment was made. Hence, it is obvious that the entity achieved the additional benefit arising from export transactions. However, as seen through the prism of changes in the exchange rate in the period from December 31 to March 14,2004 , it is obvious that the recognition of positive foreign exchange differences is the result of high variability of USD during this period. Although the operating result was exposed to variations, by hedging against the adverse exchange rate movements the planned business results were achieved. 


\section{Literatura / References}

1. Accounting Standards Council, 2006. International Financial Reporting Standard: Financial, Instruments: Recognition and Measurement, http://www.asc.gov.sg/ frs/attachments/2004/FRS_39_2006.pdf (03.10.2014)

2. Allayannis, G. J. Ihrig, and J. Weston, 2001. Exchange-Rate Hedging: Financial vs. Operational Strategies, American Economic Review Papers and Proceedings, Vol. 91 (2), pp. 391-395.

3. David, K. Eiteman, Arthur I. Stonehill, Michael H. Moffett, 2001. Multinational Business Finance, 9th ed. Boston. Addison - Wesley cop.

4. Grabbe, J. Orlin, 1983. The Pricing of Call and Put Options on Foreign Exchange, Journal of International Money and Finance, 2, 239-253.

5. Hakala, J. and U. Wystup, 2002. Foreign Exchange Risk: Models, Instruments, and Strategies, London: Risk Publications.

6. Holton, G. A. 2003. Value-at-Risk: Theory and Practice, San Diego, California: Academic Press.

7. Hull, J. C. 2005. Options, Futures and Other Derivatives, $6^{\text {th }}$ ed. Prentice Hall, Pearson education International.

8. IASB Expert Advisory Panel, 2008. Measuring and Disclosing the Fair Value of Financial Instruments in Markets that are No Longer Active, Draft Document, IASCF, 16. September 2008.
9. Iain, J. Clark, 2011. Foreign Exchange Option Pricing: A Practitioners Guide, John Wiley \& Sons, str. 21-26.

10. Jacque, L. 1996. Management and Control of Foreign Exchange Risk, Norwell, Massachusetts: Kluwer Academic Publishers.

11. Kraus, K. M. 2010. Advanced Option Trading: Approaches, Tools, and Techniques for Proffesional Traders, e-book, McGrawHill, pp. 18.

12. Lung, Pei Peter, 2001. Information content in asymmetries of call and put currency options, a Dissertation, Texas Tech University, https://repositories.tdl.org/ttuir/bitstream/handle/ (31.05.2015.).

13. Mark, B. Garman, Steven W. Kohlhagen, 1983. Foreign currency option values, Journal of International Money and Finance, Volume 2, Issue 3, December, Pages 231-237.

14. Ramirez, J. 2008. Accounting for derivatives, Chichester: John Wiley \& Sons Ltd.

15. Shapiro, A. C. 1996. Multinational Financial Management, $5^{\text {th }}$ ed. Hoboken, New Jersey:Wiley.

16. http://www.bis.org

17. http://www.ecb/historical-exchange-rates 


Table 21.
\begin{tabular}{|l|l|r|l|}
\hline 31.12 .2003 & Financing costs & $-15,423.28$ & Option time value \\
\hline 17.02 .2004 & Financing costs & $-1,048.38$ & Option time value \\
\hline 17.02 .2004 & Financing costs & $64,339.26$ & Option intrinsic value \\
\hline 17.02 .2004 & Revenue from sales & $738,839.63$ & Sale to foreign buyer \\
\hline 14.03 .2004 & Financing revenue & $37,621.34$ & Fair value of claims \\
\hline 14.03 .2004 & Financing costs & $-37,841.18$ & Option fair value \\
\hline & Total: & $786,487.39$ & \\
\hline
\end{tabular}

Source: Author

As shown in Table 21, the value of the transaction is hedged in the amount of $€$ $786,487.39$ regardless of the market oscillations of the exchange rate. This corresponds to the agreed rate of execution minus the amount of the premium paid $(803,178.90-16,691.50=$ $786,487.40)$. Hence, it can be clearly concluded that the stability of operations has remained untouched.

\section{Conclusion}

As financial derivatives, options are one of the most demanding financial forms in general. The application of options requires a lot of knowledge. Otherwise, their usage can turn into a business disaster instead of achieving the intended purposes.

Options are very interesting financial derivatives which offer the holder a range of opportunities and benefits, but because of their complexity and undeveloped market, they are still neglected in this region. A wider use of currency options is certainly not possible without the existence of available, broad and liquid market of financial derivatives. The fact is that Serbia lags behind when it comes to the development of financial derivatives and much remains to be done in this area. The world economy has been undergoing the process of globalization, while the Serbian economy, due to its small size, will not be able to remain aloof from the main economic flows much longer, like an isolated island.

For a successful implementation of currency options in the process of hedging against currency risk, it is necessary to know their nature, adopt modern knowledge, study the standards regulating their accounting treatment, improve the offer of derivatives and intensify all forms of education on hedging against currency risk. And even more so given that all entities in Serbia should be ready to welcome the development of financial derivatives which is expected sooner or later. 